\title{
The World Flora Online 2020 project: will Cameroon come up to the expectation?
}

\author{
Jean Michel Onana ${ }^{1}$
}

\begin{abstract}
Biodiverse Cameroon has been highlighted as the top country in tropical Africa for plant species diversity per degree square, with a higher diversity than all other West African countries added together, and including two of the top documented centres of plant diversity in Tropical Africa. Despite its reduced taxonomic capacity, with only six active taxonomists a high level of botanical activity in the country has resulted in accomplishments such as the databasing of the YA Herbarium (over 60,000 records), which has an in-country collection coverage of almost $95 \%$ of the known plant species that are recorded for Cameroon. Other accomplishments are the Red Data Book of the Flowering Plants of Cameroon, several local checklists and published volumes of the Flore du Cameroun which covers $37 \%$ of the country's species. Currently the checklist of Cameroon records 7,850 taxa at species and infraspecific level. Resources are needed to support and heighten the profile of this small botanical community. Already thanks to strong collaboration between Cameroon and renowned botanical institutes of others countries, in particular France and United Kingdom, one hundred and thirteen plant families have been published and would help this country to complete the recording of its biodiversity towards contributing to the World Flora Online 2020 project.
\end{abstract}

Key words: Africa, botanical research, checklist, flora, Republic of Cameroon.

\section{Resumo}

A República dos Camarões tem sido destacado como o principal país na África tropical para a diversidade de espécies de plantas por grau quadrado, com uma diversidade maior do que todos os outros países do Oeste Africano juntos, e incluindo dois dos maiores centros de diversidade de plantas documentadas na África Tropical. Apesar da sua reduzida capacidade taxonômica, com apenas seis taxonomistas ativos, um elevado nível de atividade botânica no país resultou na digitalizaçãodo herbário YA (com mais de 60.000 registros), tendo em seu acervo quase que $95 \%$ das espécies de plantas conhecidas para os Camarões. Outras conquistas para a botânica do país são o Livro Vermelho das Angiospermas dos Camarões, várias listas de verificação locais e volumes publicados da "Flore du Cameroun", que abrange $37 \%$ das espécies do país. Atualmente, a lista dos Camarões apresenta 7,850 táxons registrados tanto em nível específico como infraspecífico. Porém mais recursos financeiros são necessários para apoiar e elevar o perfil desta pequena comunidade botânica no país. Graças a uma forte colaboração entre os Camarões e renomados institutos de botânica de outros países, em especial da França e do Reino Unido, os tratamentos para cento e treze famílias de plantas já foram publicados e representam um importante passo para que este país possa completar o registro da sua biodiversidade, contribuindo assim para o projeto da Flora Mundial on-line 2020.

Palavras-chave: África, pesquisa botânica, República dos Camarões.

\section{Introduction}

As a Party of the Conference of Parties, Cameroon has accepted the duty to implement decision $\mathrm{X} / 17$ of the consolidated update of the Global Strategy for Plant Conservation for a World Flora online by 2020 (UNEP/CBD/SBSTTA/16/ $\mathrm{INF} / 38,23^{\text {rd }}$ April 2012). However, the $5^{\text {th }}$ national report for the Convention of Biodiversity - CBD (République du Cameroun 2014) did not make any mention of this global project. This does not mean that there is no intention to continue with the efforts to complete the flora of Cameroon.

According to Letouzey (1968), floristic research in Cameroon began in earnest when Gustav Mann investigated Mount Cameroon for the first

\footnotetext{
${ }^{1}$ National Herbarium of Cameroon, PO. Box 1601, Yaoundé, Cameroon and Department of Plant Biology, Faculty of Sciences, University of Yaoundé I, PO. Box 812 Yaoundé, Cameroon. jmonana2002@yahoo.fr
} 
time in December 1861. Later, several botanists travelled to Cameroon and collected material which was deposited in European Herbaria, particularly B, $\mathrm{K}$, and $\mathrm{P}$ (Holmgren et al., 1990). The creation of the Herbarium in Yaoundé dates from 1948; initially specializing in forest trees as part of the Forest Research Section of Cameroon (SRFK (Kamerun) or SRFCam). This facility was later expanded to include specimens of all vascular plants and, in 1971, it became the National Herbarium of Cameroon (YA).

The project Etude de la Flore du Cameroun has been running since 1950 with three main objectives: set up a collection of specimens of all vascular plant species of Cameroon; establish a map of the main phytochoria; and describe the material family by family in the series Flore du Cameroun (FDC). While much additional work has been carried out through different studies and projects recording and describing taxa from Cameroon, the work in the Cameroonian flora continues to move forward as our plant species become better known.

Emerging patterns from our rich flora cause the taxonomists in Cameroon to ask the following questions: What is the present situation of the flora of Cameroon? Is there a working species list? How is the species list maintained and updated? What is the methodology that Cameroon will follow to complete its flora by 2020 ? How is the local scientific community going to be coordinated and stimulated towards improving the quality of the knowledge regarding Cameroon's flora? What are the biggest challenges and obstacles envisaged in order to complete Cameroon's flora by 2020 ? How do we envisage that the data/information from the Cameroon flora will be inserted into the World Flora 2020 project? What is the importance of the World flora project for Cameroon? Before answering these questions, an overview of the location and biophysical features of the country, together with the current situation of the plant collections, collection coverage, floristic richnes estimates, state of floristic publications and an update on Cameroonian threatened plants will be presented.

\section{Methodology}

The Republic of Cameroon, covering an area of $475,442 \mathrm{~km}^{2}$, is situated in west-central Africa (Fig. 1) between latitude $1^{\circ}$ and $13^{\circ} \mathrm{N}$ and longitudes $8^{\circ}$ and $17^{\circ} \mathrm{E}$, extending from the Atlantic coastline in the south to lake Chad in the extreme north, in the Sahel at the edge of the Sahara Desert. Four major biophysical features dominate the country

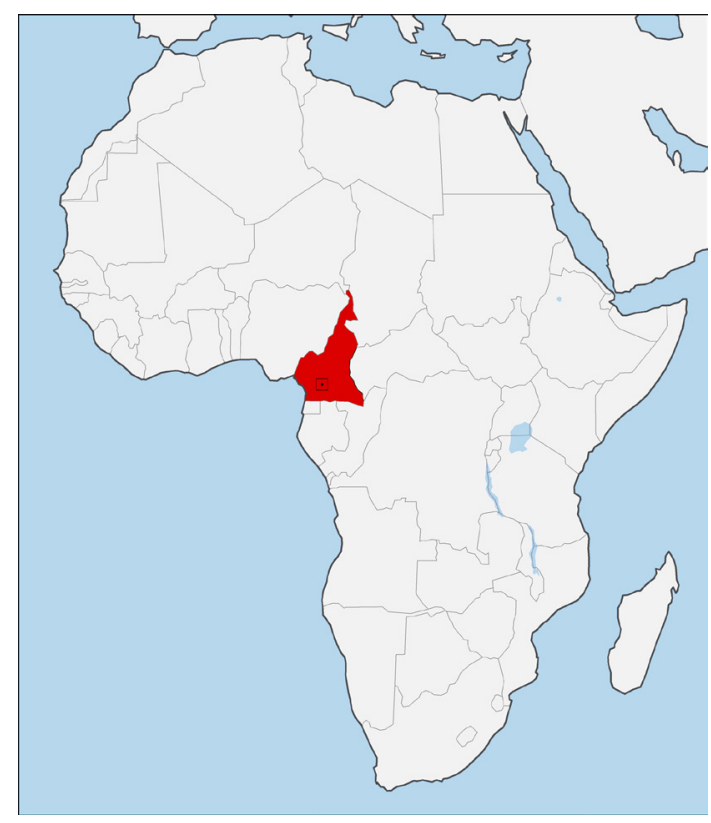

Figure 1 - Cameroon in Africa. Maps of Cameroon date 31 June 2010. From Wikimedia Commons. Author: MS Claudia. (<https://commons.wikimedia. org/wiki/File:Cameroon_(orthographic_projection). svg.>). Dowloaded 27/05/2015.

in relation to the relief and geomorphology (Morin 1979; Tchawa 2006), climate (Moby 1979; Tsaléfac 2006), including the majority of all known African vegetation types (Letouzey 1979, 1985; Onana 2013), originating the expression 'Africa in miniature' (Fig. 2). These are (from south to north):

\section{The south Cameroon plateau}

At 500-800 m altitude, occupies about a third of the country. The rainfall is generally around $1,500 \mathrm{~mm}$ per annum, with four seasons of unequal intensity divided in two wet seasons, a heavy rainy season from mid August to mid November and a light wet season from mid March to mid June; and two dry seasons, a more intense dry season from mid November to mid March and a weaker one from mid June to mid August. Semi-deciduous rain forest is the major vegetation type.

\section{The coastal plain}

Is $75-200 \mathrm{~km}$ wide, with altitude varying between sea level and $300 \mathrm{~m}$, with rainfall around 4,000 mm (exceptionally high at Cape Debundscha at the foot of Mt Cameroon on the Atlantic Ocean side, one of the five wettest places in the world, 
where it can reach over $10,000 \mathrm{~mm}$ yearly). The climate in the coastal plains is known as type camerounien with two major seasons, a long rainy season and a short dry season lasting from December to February. Ombrophilous evergreen rainforest covers the whole area.

\section{The Cameroon Highlands}

Are formed by an interrupted volcanic line from the sea to the extreme north of Cameroon in the Mandaras Mountains, with a curve on the Adamaoua plateau (1,000-1,200 m altitude). Cameroon contains Africa's highest mountains west of the Albertine Rift, namely Mount Cameroon (4,070 m), Mt Oku (3,011 $\mathrm{m})$ and Mount Bamboutos $(2,740 \mathrm{~m})$. The highlands continue off shore towards the southwest into a line of islands, most notably Bioko Island (Equatorial Guinea), São Tomé Island, Príncipe Island (both Republic of São Tomé and Príncipe) and Pangalu or Annobon Island (Equatorial Guinea). The climate is a variant of the coastal plain climate, with increased

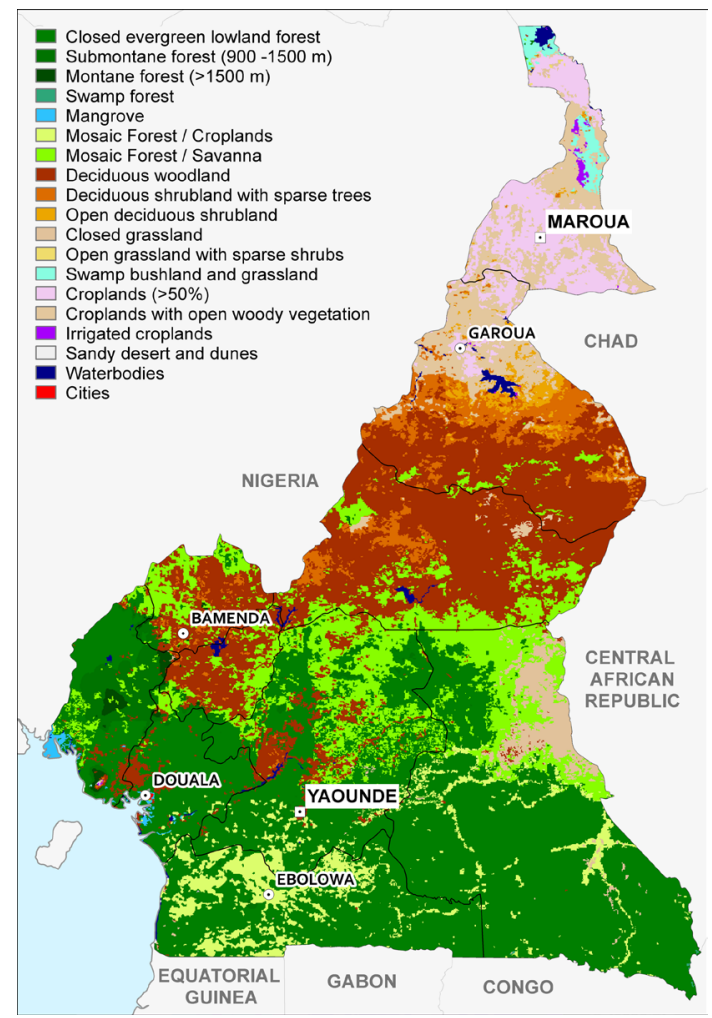

Figure 2 - Vegetation cover in Cameroon (source: Interactive Atlas of forestry resources of Cameroon, version 2.0. Cameroon Ministry of Forestry and Fauna/ World Resources Institute 2007) rainfall caused by clouds being forced up from the southwest African monsoon winds in the period April-October, the main wet season. The vegetation comprises Submontane rain forest at around 1,000 to 2,000 m alt., Montane rainforest between 2,000 and 3,000 $\mathrm{m}$ alt. to Afrosubalpine grassland and prairies over 3,000 $\mathrm{m}$ alt. on two of the mountains: Mt Oku and Mt Cameroon. On the Adamaoua, the soudanian area of the Cameroon Mountains, the highest summits are Tchabal Mbabo (2,640 m altitude), Hosséré Vokré (2,049 m), Tchabal Nganha (1,923 m) and Tchabal Ngangdaba (1,960 m). Rainfall is lower, at around 1,500 $\mathrm{mm}$ per annum. Vegetation on the plateau is Open forest to Woody savanna.

\section{The north plain plateau}

Altitude varies from $300 \mathrm{~m}$ to up to $1,442 \mathrm{~m}$ at the Mandaras Mountains, the northern portion of the Cameroonian mountains. The rainfall varies from $300 \mathrm{~mm}$ in the far north to $800 \mathrm{~mm}$ further south, with two seasons: a short rainy season from July-August to September-October and a long dry season from September-October to July-August. The tropical savanna vegetation includes Woody savanna to Herbaceous, open savanna and steppes in the extreme north.

\section{Results \\ Collections}

Around 501 expeditions involving approximately 634 botanists were carried out in Cameroon from 1861 to the turn of this century. Since then, the collection effort has been project based, involving field work for taxonomic studies or biodiversity assessments for projects involving land development and designation of protected areas (Cheek et al. 2004, 2010, 2011). According to methodology suggested by Poncy \& Labat (1994), Cameroon's density of plant collection (Fig. 3) referring to the Indices of Density of Collection (IDC) reached about 0.3 collection $/ \mathrm{km}^{2}$ (30 collections $/ 100 \mathrm{~km}^{2}$ ) in 2010 (Onana 2010). Overall, therefore, the floristics of Cameroon remains 'little known' at the botanical level when considering that a minimum rate of 1 specimen $/ \mathrm{km}^{2}$ is the acceptable value for the inventory of a territory (Campbell \& Hammond 1989).

For Cameroon, Poncy \& Labat (1994) calculated that, from a base of 10 collections/100 $\mathrm{km}^{2}\left(0,1\right.$ collections $\left./ \mathrm{km}^{2}\right)$ in 1981 , with an increase of 1,38 collections $/ 100 \mathrm{~km}^{2}$ per annum in 7 years (1974-1981), 65 years would be necessary to reach the target of 100 collections $/ 100 \mathrm{~km}^{2}$ (1 collection/ 


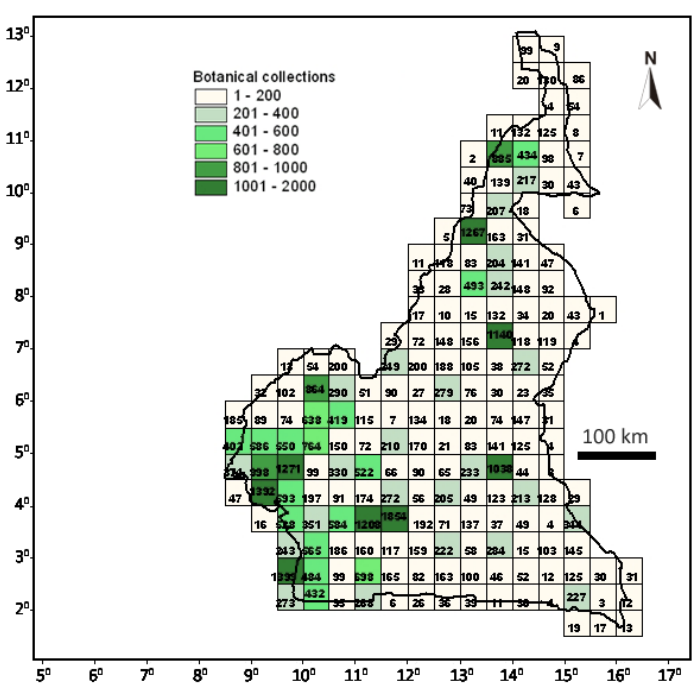

Figure 3 - Overview of botanical effort collection in Cameroon based on the distribution of 36,588 specimens at YA using half degree cells (source: Onana 2011).

$\mathrm{km}^{2}$ ); implicating that the target would be reached in 2046. In 2015, we are still very far from reaching this target. By 2015, around 65,000 specimens were incorporated in the YA working collection, with duplicates of these deposited in various Herbaria (B, BM, FHI, G, K, P, MO, SCA, WAG and Z). Considering that material of only 376 species of the 7,850 known species is not currently deposited at YA, our National Herbarium has an excellent coverage of about $95 \%$ of the total number of species recorded for Cameroon.

The database. The digitization of the label data has started in 2002 with the RIHA database on an Access platform with PostGrès (Chevillotte et al. 2006). The database is supported by the Institut de Recherche pour le Développement (IRD) and the Royal Botanic Gardens, Kew (RBG Kew). Since December 2010, all the 65,000 specimens of the working collection are included in the database. New collections are added regularly and updates continue for localities and scientific names.

\section{Floristic richness in Cameroon}

The floristic richness per experimental unit is unevenly distributed as it currently appears to follow the collection density (Fig. 4). According to Onana $(2010 \mathrm{~b}, 2011)$, the floristic richness in vascular plant species per taxa at the family, genus and species levels is as follows:

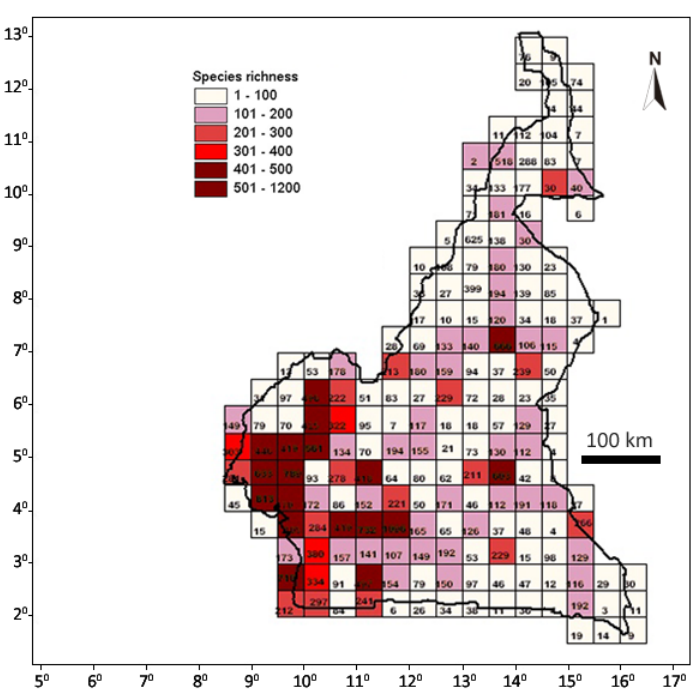

Figure 4-Overview of vascular plant species richness in Cameroon, based on the distribution of 36,588 specimens at YA using half degree cells (source: Onana 2011).

\section{Families}

The number of families of vascular plants recorded in Cameroon varies according to the system followed: according to Brummitt (1992) and Flora of Cameroon vol. 3 there are 248 families ( 25 of Pteridophyta), of them 228 being native and 20 introduced families of seed plants. According to Heywood et al. (2007) there are 195 families of flowering plants; according to APG III (APG III, 2009; Chase \& Reveal 2009) there are 182 families of flowering plants. For the non-flowering vascular plants, Roux (2009), in line with results of recent phylogenetic studies, lycophytes were separated from ferns recognizing 30 families ( 3 families for Lycopodiophyta and 27 of Pteridophyta). Using the latest phylogenetic studies (APG III) as a basis for our count, Cameroon has 212 families of vascular plants (Tracheophyta). All families known in Cameroon are represented in the collections of YA.

\section{Genera}

According to Onana (2011) there are 1,884 plant genera in Cameroon (amongst them 87 non-flowering vascular plant genera) of which 1,641 are native and 243 are introduced. The only two genera not found at YA are Namatea (Sapindaceae) and Winklerella (Podostemaceae). 


\section{Species}

From the 7,850 species reported for the Cameroonian territory 7,385 are native and 534 are introduced, of which 185 are naturalized while 349 are cultivated. Collection effort gaps need to be addressed in order to complete the records. According to Joppa et al. (2010), if the undescribed or yet unrecorded species comprise around 10-20\% of those already described (Bebber et al. 2010, Küper et al. 2006; Onana 2011), the specific richness of vascular plant species can be estimated at between 8,700 and 9,500 species.

\section{Publications on the Cameroon flora}

The series Flore du Cameroun (FDC) comprises at the moment of fourty two published volumes. Three volumes not dedicated to taxonomic treatment of families present the history of the botanical collections in Cameroon (Letouzey 1968), a checklist of the vascular plant species of Cameroon (Onana 2011) and a checklist of endemic and rare plants of Cameroon (Onana 2013). In the thirty nine volumes others, installments by botanical family include descriptions of morphological characters, illustrations, keys for genera and species, geographical distribution and citation of studied material.

The 39 volumes so far published by 38 taxonomists of c. 10 different countries of Europe and United States of America and one (NtepeNyame) from Cameroon, comprise 112 families, 624 genera and 2,269 species. An addidional publication that dealt with 433 species of grasses (van der Zon, 1992) brings the total to 2,702 taxa (37\% of the known taxa) published. The taxonomic checklist of vascular plants of Cameroon (Onana 2011) shows a total of 7,850 taxa (including subspecies and varieties). According to this figure, Cameroon is the fourth richest territory in vascular plant species in continental Africa, after South Africa (c. 23,400 species), Democratic Republic of Congo and Tanzania (c. 10,000 species each).

The following families are currently being prepared for publication: Burseraceae, Gnetaceae, Lecythidaceae, Polygalaceae and Podocarpaceae, This will increase the number of taxa published and improve the knowledge of the flora of Cameroon. At the moment genera of Annonaceae (Piptostigma), Orchidaceae (Angraecum) and Rubiaceae (Bertiera, Craterispermum, Psychotria, and Sabicea) are being studied by students developing doctoral thesis or as postdoctorate research work.
The bibliography dealing with the Cameroonian Flora also comprises around 600 papers published in peer-reviewed taxonomic journals describing new taxa or revising taxonomic groups in large families such as Rubiaceae (94 publications), Legumes (47), Acanthaceae (21), Annonaceae (18) and Euphorbiaceae (31).

According to Polhill (1990 cited by Poncy \& Labat 1994: 12) "a taxonomist working midtime can complete 50 species descriptions in a year"; thus, in order to describe the known 5,500 species of the flora of Cameroon that remain to be described, from 2015, one taxonomist would be working for 116 years, while four botanists would take 29 years. This is surely slow progress and more should be done to train and employ taxonomists and to develop further collaborations worldwide to speed up the baseline study of the flora. In a more positive light, it is worth considering that the availability of digitized type as well as nontype specimens (Darbyshire et al. 2010) and the availability of taxonomic literature online have probably improved the productivity of scientists (Onana \& Chevillotte 2015), indicating that the task may be concluded in less time (Costello et al. 2013).

\section{Local (vernacular) names}

Lists of vernacular names have been established for four national languages of the forest area, covering three administrative regions (Central, South and East - ewondo, bulu, baka or bibaya and bagueli languages) by Onana \& Mezili (in prep.) and languages for the tropical savanna area of the North and Far North (fufulde, guizigua, hoho, madan, mafa, toupouri, massa, zoulgo) by Ntoupka (in prep.) The manuscripts for these lists remain unpublished, but the plan is to publish these data within the FDC series.

\section{Threatened flowering plant species of}

\section{Cameroon.}

Studies were carried out to catalogue the threatened flowering plants species and their distribution and endemism. In the Red Data Book of flowering plant species of Cameroon (Onana \& Cheek 2011), 815 flowering plant species are documented, including a map for each species evaluated as threatened using IUCN global assessments (IUCN 2001), most of them having been assessed for the first time. The limitations in the work are due to the impossibility to assess 
families that lack a recent revision (Cheek in Onana \& Cheek 2011). Since numerous species occur beyond Cameroon, the new assessments are also relevant to Nigeria, Gabon, and as far west as Guinea, Ivory Coast, to east as Congo, Rwanda and Burundi. The hotspots defined as areas of concentration of threatened species are shown on a map at the back cover (Fig. 5), where it can be seen that the Afromontane Archipelago Centre of endemism (White 1983) harbours the majority of threatened species, followed by the Lower Guinea Centre of endemism. The assessments are now in the process of validation via the Species Information Service (SIS) of IUCN. At the moment 100 of these assessments have been published in October 2014 on the IUCN website ( $<$ http://www. iucnredlist.org/>).

\section{Endemic and rare plant species}

The synopsis of endemic and rare species of vascular plant species of Cameroon (Onana 2013), where species represented by between one and ten collections are considered rare, documents 1,689 species (including infraspecific taxa), among them 585 known only in Cameroon and thus considered endemic sensu stricto. The synopsis records the habit, habitat, distribution, state of endemism and rarity and the IUCN (2001) status at the global level.

\section{Discussion}

Highlights regarding native species diversity in Cameroon are:

Cameroon is believed to be the top country in tropical Africa for plant species diversity per degree square (Barthlott et al. 1996) with more than 5,000 species per degree square in parts of the southwest of the country;

Cameroon alone has higher plant species diversity than the all the other countries in West Africa, from Senegal to Nigeria added (Cheek \& Onana 2011);

The top documented centres of plant diversity in Tropical Africa are Mount Cameroon (2,435 species) and Mt Kupe - Bakossi Mountains (2,412 species) (Cheek \& Onana 2011) and Kribi-Campo area (2,297 species) (Tchouto 2004; Tchouto \& Elad 2010).

\section{Cameroon's working plant list}

The richness of the flora of Cameroon was evaluated by reference to the working collection in YA (Satabié 1999). The need for a list of accepted scientific names for the vascular plants of Cameroon is evident, because the information is contained in a large volume of taxonomic works, several recent regional floras, as well as electronic initiatives, such as the World Checklists of Selected Plant Families on-line (WCSP 2015) and the digitization of data in herbaria worldwide and at the YA Herbarium. The first species taxonomic checklist for Cameroon was published in 2011 (Onana 2011).

The checklist comprises the groups of the vascular species: Angiosperms, Gymnosperms, Pteridophytes and Lycophytes. The taxonomic checklist comprises 7850 scientific names, followed by their IUCN status. The checklist serves as baseline for the Red data Book of flowering Plants of Cameroon (Onana \& Cheek 2011). When crosschecked with the list of accepted names on-line (The Plant List 2013), it is found that 6,166 of these names are accepted, 936 are considered synonyms and the status of 748 names comprises unresolved names, names not currently found in The Plant List and different spellings. The necessary updates and corrections are being implemented.

\section{How is the species list maintained and updated}

The Cameroon taxonomic checklist is supposed to be updated every five years. The methodology is to check regularly the taxonomic works in which material from Cameroon is cited. During the period April 2011 to August 2015, 36 new species have been recorded as follows: Afrothismia (2); Crateranthus (1), Cryptosepalum (1), Cyperus (1), Distylodon (1), Dracaena (1), Gilbertiodendron (4), Globulostylis (3), Gnetum (2); Hymenostegia (1); Kihansia (1), Leptonychia (3), Massularia (1), Memecylon (3), Napoleonaea (1), Neuropeltis (1), Polystachya (1), Psychotria (2), Rhipidoglossum (1), Sabicea (1) and Vepris (5). During the same period, few previously accepted in Globulostylis (1) and Vepris (1), have been synonymized. In total, about 34 names species can be added to the list, bringing the actual number of known species to 7,884 .

At present, it is important to push for publication of more revision of taxonomic group, including work regarding taxa already published in the FDC series, for example the work by Onana \& Chevillotte (2015) complementing the volume on Rutaceae published in 1963; Stone (2015) 


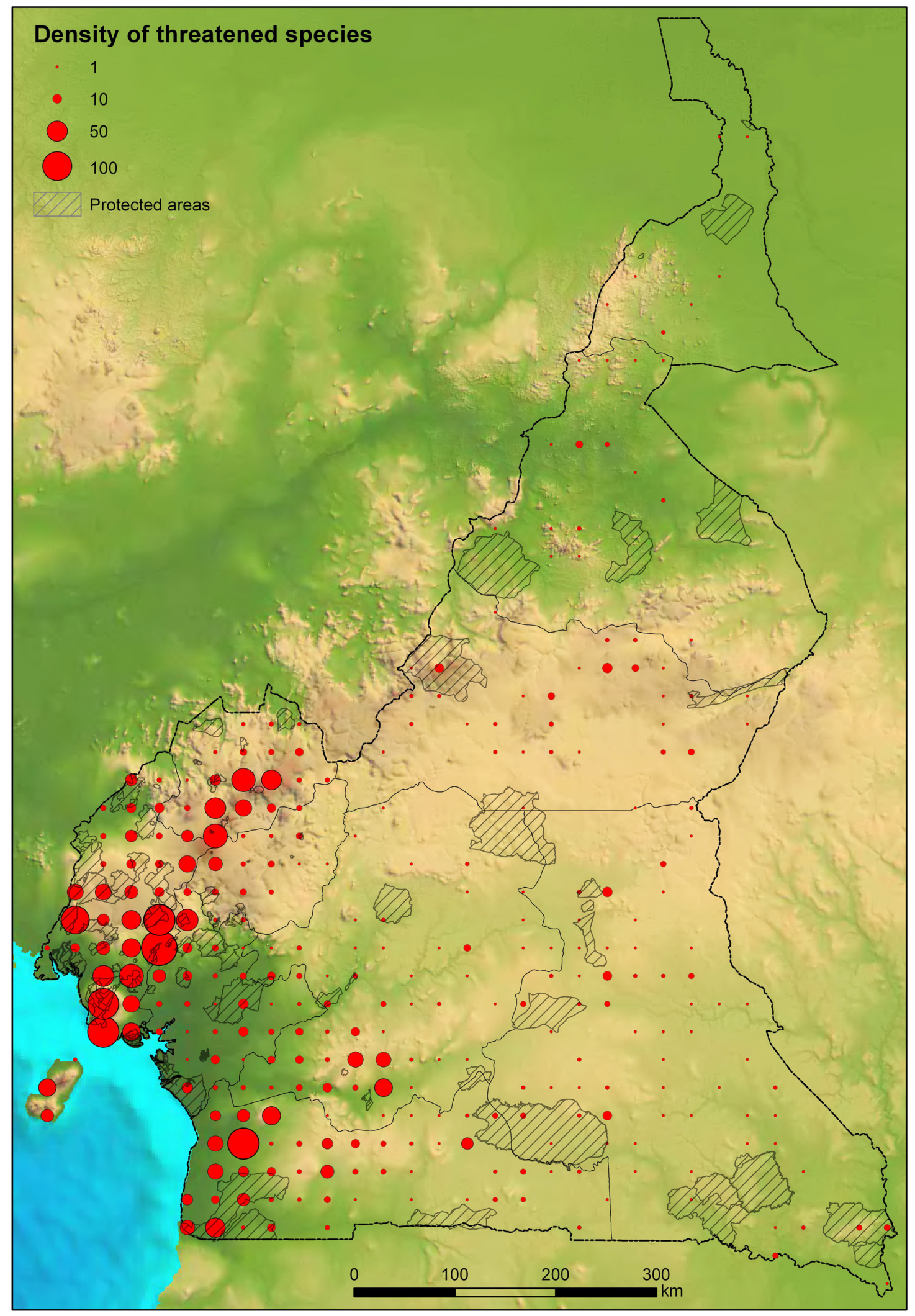

Figure 5 - Overview of hotspots of flowering plants in Cameroon (source: Onana \& Cheek 2011, back cover ) 
and Stone et al. (2008) for the Melastomataceae (volume published in 1983); van der Burgt (2010) for the Chrysobalanaceae (published in 1978); van der Burgt (2009), van der Burgt \& Newbery (2006) for the Sapotaceae (published in 1964); and van der Burgt et al. $(2012,2015)$ for LeguminosaeCaesalpinioideae (published in 1970). New volumes of FDC dealing with families not yet treated, and the production of a more documented checklist including additional data such as habit, distribution and voucher specimens are all priorities to further the knowledge of Cameroonian plants.

\section{Methodology to complete the Flora}

The World Flora 2020 project is not implemented in Cameroon as a project by itself. Floristic research is done in the framework of the project Etude de la Flore du Cameroun which aims to describe all the vascular plants of Cameroon and to publish in the FDC series. The project has no timetable and volumes are published as opportunities arise, on a voluntary basis, by taxonomists who are studying the flora of the country.

\section{Coordinating and stimulating the local scientific community towards improving the quality of the knowledge regarding Cameroon's flora}

The Cameroonian scientific community for plant taxonomy is very small and the country lacks resources. Currently the local scientific community count only six active plant taxonomists among them three at YA Herbarium: Ghoghe Jean Paul (Annonaceae, Podostemaceae), Tchiengue (Guttiferae) and Onana Jean Michel (Burseraceae, Rutaceae); a further two at the University of Yaoundé I: Biye Elvira (Gnetaceae) and Sonké Bonaventure (Rubiaceae); and Sainge Moses (Thismiaceae) at the University of Buea. Floristic research in Cameroon is coordinated by the Head of the National Herbarium (YA) who is, in fact, the principal investigator of the project to study the country's flora. One of his duties is to stimulate the description of plants of Cameroon by exchange of material with foreign taxonomists who cannot travel to Cameroon, getting authorization of research and welcoming others for field work and helping students in the herbarium for their academic works.

In addition, the taxonomists working as lecturers at the University of Yaoundé I describe species as part of their research, participating in the
Flora of Cameroon project as associate researchers or fellows.

\section{Biggest challenges and obstacles to completion of the Flora of Cameroon by 2020}

In order to be able to complete the Flora of Cameroon by 2020, solutions for the following big obstacles need to be found:

- The lack of plant taxonomists (Surtcliffe \& O'Reilly 2010) is acute in Cameroon at present, with only four taxonomists regularly describing and publishing new taxa or revisions, and further two who have sporadically described new species in the five last years but are not working in floristic research. The lack of opportunity and stimulation for a carrier as plant taxonomist is the main reason why the three scientists who have completed their PhD in plant taxonomy (Kenfack 2008; Nguembou 2008; Taedoung 2014) left plant taxonomy for other fields such as forestry conservation.

Taxonomic research is not amongst the country's priorities. In a developing country context where one of the big questions is food security, biodiversity research that leads to conservation is regarded as a possible obstacle for the development of agricultural activities, causing plant taxonomy research to be relegated to the lowest rank of priorities, with almost inexistent funding.

It is an increasing challenge to convince taxonomists to agree to produce family accounts for Cameroon. There are no more taxonomists working on African tropical plants at the Muséum National d'Histoire Naturelle in Paris (P Herbarium), the main partner for the production of floras in French. Other European and North American institutions are following the same direction, giving preference to other types of research such as molecular biology, as these papers can be published in journals with higher impact. The result is that they neglect the need to produce baseline data to address the knowledge of floras at local, country and regional levels.

- The lack of funding allocated to research and development also impacts upon the maintenance of collections, laboratories and general working conditions for taxonomists.

\section{Data and information provision from Cameroon flora to the World Flora project}

Amongst the avenues that could be explored to ensure continuation of taxonomic research regarding the Flora of Cameroon, existing collaboration should be formalized by the signature of a Memorandum 
of Collaboration (MOC) between the Royal Botanic Gardens, Kew (RBG, Kew) and the National Herbarium of Cameroon (NHC). This important collaboration lead to the completion of a large number of conservation-lead projects, achieving the production of ten checklists, including seven regional checklists (Cable \& Cheek 1998; Cheek et al. 2000, 2004, 2010, 2011; Harvey et al. 2004, 2010) with IUCN assessments at global level, a Red Data Book of flowering plants with IUCN assessments at global level (Onana \& Cheek 2011), a taxonomic checklist (Onana 2011) and a checklist of endemic and rare species at the national level (Onana 2013). The purpose of signing a MOC would be to support the inclusion of NHC data amongst the contents of the World Flora 2020 project.

The past record of RBG, Kew working together with NHC has helped the latter's involvement in collection-based international projects such as African Plant Initiative (API) and Global Plants Initiative (GPI) with 1002 items (images of types and endemic species specimens) from NHC available on-line through JSTOR Global Plants $(<\mathrm{http}: / / w w w$. lants.jstor.org $>)$. Similarly, French cooperation through the Institut de Recherche pour le Développement (IRD) and the Museum national d'Histoire naturelle de Paris, with the database comprising herbarium label data that began in 2002 and is still ongoing. Data from 65,000 specimens of the working collection are already in the database. In the past, French cooperation has helped Cameroon to establish its portal for the Global Biodiversity Information Facility (GBIF), the Cameroon Biodiversity Information Facility (CamBIF) with a pilot project which permitted the insertion of $\mathrm{c}$. 5,000 primary plant data records in the international network database of GBIF.

The Clearing House Mechanism (CHM) of the Ministry of the Environment of Cameroon, the Protection of Nature and Sustainable Development (MINEPDED) has implemented the establishment of a centre for documentation on biodiversity. This is an opportunity to establish a MOU between the NHC, the CHM Cameroon and key partners such as the RBG, Kew to stimulate the production of data/ information which will be displayed by the CHM website and could then be transferred to the World Flora project.

\section{The importance of the World Flora project}

From the national point of view, and departing from the principle that "a flora is only useful after it is complete" (van Steenis cited by Poncy \& Labat 1994), it is expected that the completion of the World Flora will:

Help to provide tools (keys, photographs, descriptions, distribution data) for plant identification. Facilities such as The Plant List (2013) already help to update the taxonomic status of names, even though the list is static and many names there remain unresolved.

Indicate the global distribution of species. This will help to improve the knowledge of endemism, restricted distributions, rarity and other distribution patterns, such as disjunctions. The phytogeography and biogeography of our vegetation will benefit from a better understanding regarding the floristic diversity and dynamics of our ecosystems.

Provide a baseline framework for the compilation of plant information, including traditional knowledge and vernacular names.

Stimulate the production of the flora at national level. The families in the FDC series have not been described by Cameroonian-based taxonomists but by researchers studying plant groups at the African or global level. It may facilitate the extraction of the data relevant for Cameroon in the long run.

Provide guidance regarding names and distribution of potential invasive species.

At the global level, a comprehensive global flora programme will encourage many countries to begin or continue producing and updating their Floras, and those may be expanded to include other items, such as traditional knowledge. The World Flora 2020 may raise the profile of floristic activities and direct the attention from our authorities to global activities and enable us to obtain funding for our currently undervalued projects.

\section{Conclusion}

Although the 2020 World Flora Online project is not explicitly mentioned in the research agenda of the Flora of Cameroon, different aspects of it are currently being implemented. The production of a checklist of vascular species is well advanced and backed by a database that allows the list to be updated and corrected. Cameroon's contribution, together with its European partners, such as IRD and RBG Kew, will hopefully accelerate the production of volumes of the Flore du Cameroun and, at the same time, provide needed information for the establishment of a complete World Flora that will hopefully include the endemic species from rich and diverse Cameroon. 


\section{Acknowledgements}

The author would like to thank Heads of the fomer Laboratoire de Phanérogamie, Museum national d'Histoire naturelle de Paris and the Keepers of the Herbarium, Archives and Library of the Royal Botanic Gardens (RBG), Kew and particulary Dr Martin Cheek formerly Head of the wet tropic Africa team in RBG, Kew for their important commitment to the knowledge of the flora and vegetation of Cameroon. I'm also grateful to Dr Daniela Zappi of RBG, Kew for the translation of the summary in Portuguese, and the critical comments on the first version of this paper, and to the two anonymous reviewers for their relevant comments which help to improve the first version of the manuscript. Heartfelt thanks go to all taxonomists who described plants from Cameroon over the years.

\section{References}

APG III (2009). An update of the Angiosperm Phylogeny Group classification for the orders and families of flowering plants: APG III. Botanical Journal of the Linnean Society 161: 105-121.

Barthlott, W.; Lauer, W. \& Placke A. 1996. Global distribution of species diversity in vascular plants: towards a world map of phytodiversity. Erkunde band 50: 317-328.

Bebber, D.P.; Carine, M.A.; Wood, J.R.I.; Wortley, A.H.; Harris, D.J.; Prance, G.T.; Davidse, G.; Paige, J.; Pennington, T.G.; Robson, N.K.B. \& Scotland, R.W. 2010. Herbaria are a major frontier for species discovery. Proceedings of the National Academy of Sciences of the U.S.A. Available at $<\mathrm{http} / / \mathrm{www}$. pnas.org $/$ cgi $/$ contens $/$ short $/ 1011841108>$. Access on 28 May 2013.

Brummitt, R.K. (ed.). 1992. Vascular plant families and genera. Royal Botanic Gardens, Kew. 804 p.

Cable, S. \& Cheek, M. 1998. The plants of Mount Cameroon. A conservation checklist. Royal Botanic Gardens, Kew. 198p.

Campbell, D.G \& Hammond H.D. (eds.). 1989. Floristic inventory of tropical countries. New York Botanical Garden, New York. 545p.

Chase, M.W \& Reveal, J.L. 2009. A phylogenetic classification of the land plants to accompagny APG III. Botanical Journal of the Linnean Society 161: 122-127.

Cheek, M. 2011. Limitations: future work needed. In: Onana, J.M. \& Cheek, M. (eds.). Red Data Book of the flowering plants of Cameroon: IUCN global assessments. Royal Botanic Gardens, Kew. Pp. 26-27.

Cheek M.; Harvey Y. \& Onana J.-M. 2010. The Plants of Dom, Bamenda highlands, Cameroon. A conservation checklist. Royal Botanic Gardens, Kew. 162p.

Cheek M.; Harvey Y. \& Onana J.-M. 2011. The Plants of Mefou proposed national park, Yaoundé, Cameroon. A conservation checklist. Royal Botanic Gardens, Kew. 251p.

Cheek, M. \& Onana, J.M. 2011. Red data plant species in Cameroon. A guide for secondary schools teachers, Royal Botanic Gardens, Kew. 17p.

Cheek M.; Onana, J.M. \& Pollard B.J. 2000. The Plants of Mount Oku and the Ijim ridge, Cameroon. A conservation check-list. Royal Botanic Gardens, Kew. 211p.

Cheek M.; Pollard, B.J.; Darbyshire, I.; Onana, J.M. \& Wild, C. 2004. The plants of Monts Kupe, Bakossi and Mwanengouba. A conservation check list. Royal Botanic Gardens, Kew. 504p.

Chevillotte, H. \& Florence, J. with the collaboration of Achoundong, G.; Chenin, E.; Ghogue, J.P.; Hoff M.; Labat, J.N.; Murail, J.-F. \& Poncy, O. 2006 RIHA, a database on plants biodiversity in Western and Central Africa: first step for a networking of African herbaria. In: Ghazanfar S.A. \& Beentje H. (eds). Taxonomy and ecology of African plants, their conservation and sustainable use. Royal Botanic Gardens, Kew. Pp. 643-650.

Costello, M.J.; May, R.M. \& Stork, N.E. 2013. Can we name Earth's species before they go Extinct? Science 339: 413-416. DOI: 10.1126/science. 1230318.

Darbyshire, I.; Saltmarsh, A. \& Malcolm, P. 2010. Application of the ALUKA African plants resource to African Flora projects. In: Burgt, X. van der.; Maesen, J. van der. \& Onana, J.-M. (eds), Systematics and Conservation of African Plants. Royal Botanic Gardens, Kew. Pp. 771-779.

Harvey Y.; Pollard B.J.; Darbyshire I.; Onana J.-M. \& Cheek M. 2004. The plants of Bali Ngemba forest reserve. A Conservation check list. Royal Botanic Gardens, Kew. 154p.

Harvey Y.; Tchiengue, B. \& Cheek M. 2010. The plants of Lebialem Highlands, Cameroon. A Conservation checklist. Royal Botanic Gardens, Kew. 170p.

Haston, E.; Richardson, J.E.; Stevens, P.F.; Chase, M.W. \& Harris, D.J. 2009. The Linear Angiosperm Phylogeny Group (LAPG) III: a linear sequence of the families in APG III. Botanical Journal of the Linnean Society 161: 128-131.

Holmgren, P.K.; Holmgren, N.H. \& Barnett, L.C. 1990. Index Herbariorum. $8^{\text {th }}$ ed. New York Botanical Garden, New York. 693p.

IUCN. 2001. IUCN Red list categories and criteria: version 3.1. Second edition IUCN Species Survival Commission. IUCN, Gland, Switzerland and Cambridge. 32p.

Joppa, L.N.; Roberts, D.L. \& Pimm, S.L. 2011. How many species of flowering plants are there? 
Proceedings of the Royal Society of London, serie B. Biological Sciences 278: 554-559. DOI: 10.1098/rspb.2010.1004.

Kenfack, D. 2008. Systematic studies in Carapa (Meliaceae-Swietenioideae). Ph.D.Thesis. University of Missouri-Saint Louis, Saint Louis. $265 \mathrm{p}$.

Küper, W.; Sommer, J.H.; Lowett, J.C. \& Bartholott, W. 2006. Deficiency in African plant distribution data - missing pieces of the puzzle. Botanical Journal of the Linnean Society 150: 355-368.

Letouzey, R. 1968. Les botanistes au Cameroun. In: Aubréville, A. (ed.). Flore du Cameroun 7. Muséum national d'Histoire naturelle, Paris. 110p.

Letouzey, R. 1979. Végétation. In: Laclavère, G. (ed.). Atlas de la République Unie du Cameroun. Les Editions J.A., Paris. Pp. 20-23.

Letouzey, R. 1985. Carte Phytogéographique du Cameroun au 1: 500 000, accompagnée de la Notice en cinq fascicules: 1) S-S: Domaine sahélien et soudanien; 2) M-SM: Région montagnarde et étage submontagnard ; 3) SC: Domaine de la forêt dense humide semi-caducifoliée ; 4) TV: Domaine de la forêt dense humide toujours verte. Institut de la Carte Internationale de la Végétation, Toulouse. 240p.

Morin, S. 1979a. Relief et hydrographie. In: Laclavère, G. (ed.). Atlas de la République Unie du Cameroun. Les Editions J.A., Paris. Pp. 5-8.

Morin, S. 1979b. Géomorphologie. In: Laclavère, G. (ed.). Atlas de la République Unie du Cameroun. Les Editions J.A., Paris. Pp. 13-15.

Ngembou K.C. 2008. Phylogénie, distribution, écologie et révision taxonomique du genre Bertiera (Rubiaceae) en Afrique. Thèse de Doctorat en Sciences. Université Libre de Bruxelles, Bruxelles. $225 \mathrm{p}$.

Onana, J.M. 2010. Etat de connaissance de la flore du Cameroun. In: van der Burgt, X.M.; van der Maesen, L.J.G. \& Onana, J.M. (eds.). Systématique et Conservation des Plantes Africaines. Royal Botanic Gardens, Kew. Pp. 557-569.

Onana, J.M. 2011. The vascular plants of Cameroon. A taxonomic check list with IUCN assessements. Flore du Cameroun 39. IRAD-National Herbarium of Cameroon, Yaoundé. 195p.

Onana, J.M. 2013. Synopsis des espèces végétales vasculaires endémiques et rares du Cameroun. Check-liste pour la conservation et la gestion durable de la biodiversité. In: Onana J.-M. (ed.). Flore du Cameroun 40. Ministère de la Recherche Scientifique et de l'Innovation, Yaoundé. 279p

Onana, J.M. 2013. Environnement biophysique, In: Onana, J.-M (ed.). Synopsis des espèces végétales vasculaires endémiques et rares du Cameroun. Checkliste pour la conservation et la gestion durable de la biodiversité. Flore du Cameroun
40. Ministère de la Recherche Scientifique et de l'Innovation, Yaoundé. Pp. 6-23

Onana, J.-M. \& Cheek, M. 2011. Red Data Book of the flowering plants of Cameroon: IUCN global assessments. Royal Botanic Gardens, Kew. 578p.

Onana J.M. \& Chevillotte H. 2015. Taxonomie des Rutaceae-Toddalieae du Cameroun revisitée: découverte de quatre espèces nouvelles, validation d'une combinaison nouvelle et véritable identité de deux autres espèces de Vepris Comm. ex A.Juss. Adansonia, sér. 3, 37: 103-129.

Poncy, O \& Labat, J.-N. Etat actuel de l'inventaire des flores tropicales. Conférence lors des Journées annuelles de la Société française de systématique en septembre 1994, Paris. Document non publié.

République du Cameroun. 2014. Cinquième Rapport National du Cameroun à la Convention de la Diversité Biologique - Ministère de l'Environnement, de la Protection de la Nature et du Développement Durable. 100p.

Roux, J.P. 2009. Synopsis of Lycopodiophyta and Pteridophyta of Africa, Madagascar and neighbouring islands. Strelitza 23. South African Biodiversity Institute, Pretoria. 296p.

Satabié, B. 1999. Contribution à la connaissance de la biodiversité de la flore camerounaise. In: Timberlake, J. \& Kativu, S. (eds.). African Plants: Biodiversity, Taxonomy and Uses. Royal Botanic Gardens, Kew. Pp. 279-281.

Stone, R.D. 2015. Taxonomic treatment of Memecylon L. section Felixiocylon R.D.Stone (Melastomataceae), with descriptions of four new species from Cameroon, Gabon, and Equatorial Guinea (Bioko). Adansonia, sér. 3, 37: 47-61.

Stone R.D.; Ghogue J.-P. \& Cheek M. 2008. Revised treatment of Memecylon sect. Afzeliana (Melastomataceae: Olisbeoideae), including three new species from Cameroon. Kew Bull 63: 227-241.

Surtcliffe, J. \& O’Reilly, C. (2010). Ecological skills: mind the gap(s). Kew Bulletin 65 : 529-538.

Taedoumg, E.H. 2014. Etude biosystématique du genre Cratrispermum Benth.(Rubiaceae) en Afrique continentale. Thèse de Doctorat/PhD. Université de Yaoundé I, Yaoundé. 269p.

The Plant List. 2013. Version 1.1. Published on the Internet. Available at $<$ http://www.theplantlist. org/>. Access on 6 June 2015.

Tchawa, P. 2006. Relief et hydrographie. In: Ben Yamed, D.; Houstin, N \& Seignobos, C. (eds.). Cameroun. Atlas de l'Afrique. Les Editions J.A., Paris. Pp. 58-59.

Tchouto, M.P.G. 2004. Plant diversity in a Central African rain forest: implication for conservation in Cameroon. PhD Thesis. Wageningen University, The Netherlands. 208p. 
Tchouto, M.G.P. \& Elad, M. 2010. Liana composition and diversity in the Campo-Ma'an rainforest in southern Cameroon. In: van der Burgt, X.M.; van der Maesen, J. \& Onana, J.-M. (eds.). Systematics and conservation of African plants. Royal Botanic Gardens, Kew. Pp 709-719.

Tsaléfac, M. 2006. Climat. In: Ben Yamed, D.; Houstin, N. \& Seignobos, C. (eds.). Cameroun. Atlas de l'Afrique. Les Editions J.A., Paris. Pp. 62-63.

van der Burgt, X.M. 2009. Lecomtedoxa plumosa (Sapotaceae), a new tree species from Korup National Park, Cameroon. Kew Bulletin 64: 313-317.

van der Burgt, X.M. 2010. Two new taxa in Magnistipula (Chrysobalanaceae) from Korup National Park, Cameroon. Plant Ecology and Evolution 143: 191-198.

van der Burgt, X.M.; Eyakwe, M. \& Motoh, J. 2012. Gilbertiodendron newberyi (Leguminosae: Caesalpinioideae) a new tree species from Korup National Park, Cameroon. Kew Bulletin 67 : 51-57. van der Burgt, X.M. \& Newbery, D.M. 2006. Glumea korupensis (Sapotaceae), a new tree from Korup National Park, Cameroun. Kew Bulletin 61: 79-84.

van der Burgt, X.M.; Mackinder, B.A.; Wieringa, J.J. \& de la Estrella, M. 2015. The Gilbertiodendron ogoouense species complex (Leguminosae: Caesalpinioideae), Central Africa. Kew Bulletin 70: 29. DOI: 10.1007/ S12225-015-9579-4.

van der Zon, A.P.M. 1992. Graminées du Cameroun 2. Wageningen. Agricultural University Papers 92: 1-557.

White, F. 1983. The vegetation of Africa. In: UNESCO (ed.). A descriptive memoir to accompagny the U.N.E.S.C.O. / AETFAT / UNSO Vegetation Map of Africa. UNESCO, Paris. 356p.

WCSP. 2015. World checklist of selected plant families. Facilitated by the Royal Botanic Gardens, Kew. Published on the Internet. Available at $<$ http:// apps.kew.org/wcsp/>. Access 6 June 2015. 